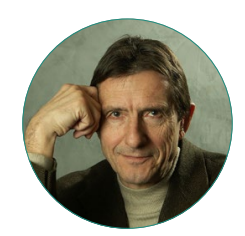

\author{
Н. П. Попов
}

\title{
ДОНАЛЬД ТРАМП И АМЕРИКАНСКИЙ АВТОРИТАРИЗМ
}

\section{Правильная ссылка на статью:}

Попов Н. П. Дональд Трамп и американский авторитаризм // Мониторинг общественного мнения: экономические и социальные перемены. 2021. № 2. С. 234-254. https:// doi.org/10.14515/monitoring.2021.2.1940.

\section{For citation:}

Popov N. P. (2021) Donald Trump and the American Authoritarianism. Monitoring of Public Opinion: Economic and Social Changes. No. 2. P. 234-254. https://doi.org/10.14515/monitoring. 2021.2.1940. (In Russ.) 
ДОНАЛЬД ТРАМП И АМЕРИКАНСКИЙ АВТОРИТАРИЗМ

ПОПОВ Николай Петрович - доктор исторических наук, ведущий научный сотрудник, Институт США и Канады РАН, Москва, Россия

E-MAIL: popovnpkm@mail.ru https://orcid.org/0000-0002-2168-2157

Аннотация. Выдвижение Дональда Трампа кандидатом республиканской партии и его победа на выборах 2016 г. над опытным политиком Хилари Клинтон для многих стали неожиданностью. Социологические исследования показывали, что Трамп использовал широко распространившиеся идеи авторитарного правления, правого консерватизма и расизма. Его поддержали люди разных политических взглядов, объединенные стремлением выдвинуть сильного авторитарного лидера, который вернет уважение белой Америке, восстановит рабочий класс, перекроет бесконтрольную иммиграцию, возродит традиционные ценности в противовес новым «аморальным" нормам. Этот слой людей оказался сплоченным, их авторитарные и расистские воззрения обрели агрессивную форму и привели к готовности применять насилие против нонконформистов, сторонников Демократической партии и ее лидеров, членов аут-групп, чьи взгляды не вписываются в представления об американских нормах и традициях. Данные выводы социологов подтвердились, когда сторонники уходящего президента штурмовали Капитолий в попытке силой добиться победы на выборах Трампа, а не Байдена.

В работе рассматриваются слагаемые авторитарного класса - право-

\section{DONALD TRUMP AND THE AMERICAN AUTHORITARIANISM}

Nikolay P. POPOV ${ }^{1}$ - Dr. Sci. (Hist.), Leading Research Fellow

E-MAIL: popovnpkm@mail.ru

https://orcid.org/0000-0002-2168-2157

\footnotetext{
1 Institute for US and Canadian Studies,

Russian Academy of Sciences, Moscow, Russia
}

Abstract. The nomination of Donald Trump as the candidate of the Republican Party and his 2016 election victory over the experienced politician Hillary Clinton came as a surprise to a large part of society. Sociological research has shown that Trump exploited widespread ideas of authoritarianism, right-wing conservatism, and racism. He was supported by people of different political views, united by the desire to nominate a strong authoritarian leader who will restore respect to white America, reinforce the working class, stop uncontrolled immigration, and promote traditional values as opposed to new "immoral" norms. This group of people turned out to be united, their authoritarian and racist views took on an aggressive form and led to a willingness to use violence against non-conformists, members of out-groups who do not fit into their ideas about American norms and traditions, and supporters of the Democratic Party and its leaders. These sociological findings were confirmed when supporters of the outgoing president stormed the Capitol in an attempt to force Trump to win the election over Biden.

The paper examines the components of the authoritarian class - right-wing conservative, racist groups and movements, such as the Tea Party movement. The author analyses reasons leading, espe- 
консервативные, расистские группы и течения, такие как "Чайное движение". Анализируются причины, приводящие, особенно в последние десятилетия, к росту авторитарных настроений и их проявлений в американской политике.

Ключевые слова: президент Трамп, президентские выборы, общественное мнение, взгляды избирателей, авторитаризм, Республиканская партия cially in recent decades, to the growth of authoritarian sentiments and their manifestations in American politics.

Keywords: President Trump, presidential election, public opinion, voters' attitudes, authoritarianism, Republican party

Когда Теодор Адорно исследовал в конце 1920-х годов авторитаризм в Германии и массовые представления людей, питающие антисемитизм и нацизм, он вряд ли предполагал, что его исследования приведут к изучению истоков и проявлений авторитарных настроений в США, оплоте демократии, где ему пришлось спасаться от нацизма после прихода Гитлера к власти.

В 2016 г. президентом стал Дональд Трамп, зарекомендовавший себя как самоуверенный, авантюристичный политик, готовый на любые недемократические шаги для борьбы со своими противниками. Многие характеризовали его методы и политический стиль как авторитарные, представляющие опасность для американской политической системы и традиций либеральной демократии. Однако мало кто предполагал, что склонность к авторитарным методам правления 45-го президента США превзойдет всех предшественников.

Серьезным предупреждением опасности взглядов Трампа и его сторонников в Республиканской партии для демократии стала вышедшая летом 2020 г. книга Б. Альтемейера и Дж. Дина "Авторитарный кошмар: Трамп и его последователи" [Dean, Altemeyer, 2020]. В ней авторы на основе социологических исследований раскрыли риски для демократических норм, выборов, законности и безопасности общества, возникшие из-за широко распространившихся авторитарных убеждений, поддерживаемых президентом Трампом. "Дональд Трамп имеет право выставлять напоказ американские институты, договоры и законы только потому, что у него есть большая преданная база, которая будет верить всему, что он говорит, и делать все, что он хочет, - пишут авторы. - Мы считаем, что бесконечная лояльность этой базы проистекает из той же психологической черты, которая, по мнению некоторых наблюдателей, глубоко укоренилась в самом Дональде Трампе,- -авторитаризма. Наше понимание этих людей основано на десятилетиях исследований людей, которые вполне могли бы поддержать автократический захват демократии" [Dean, Altemeyer, 2020: 6].

Алармизм выводов авторов не был услышан, к тому же внимание общества было отвлечено паникой, вызванной пандемией новой коронавирусной инфекции. Исследования показали, что авторитаристы готовы применить насилие к несогласным, "врагам народа", противникам авторитарного лидера. Американская реальность неожиданно быстро подтвердила справедливость научных прогнозов. 
6 января 2021 г. общее заседание двух палат конгресса должно было утвердить уже прошедшие предварительные стадии результаты подсчета голосов выборщиков. Это был заключительный формальный акт выборов, который проводил вице-президент М. Пенс. Однако проигравший выборы Д. Трамп, утверждавший, что подсчет голосов был подтасован демократами и победил на самом деле с большим отрывом он, призвал своих сторонников "не дать украсть у нас победу", идти маршем к Капитолию, не дать утвердить списки и заменить выборщиков на «правильных".

Тысячи сторонников Трампа с флагами, транспарантами, палками, железными трубами двинулись к Капитолию, сопровождаемые призывами Трампа в Twitter. Остановленные заградительными решетками, они стали штурмовать парапет здания, балконы. Все это показывалось телевидением в прямом эфире по всему миру. Сцены были похожи на кадры снятого в 1920 г. постановочного фильма С. Эйзенштейна "Октябрь" о штурме Зимнего дворца, только здесь все происходило в реальности. После рукопашных боев с охраной толпа ворвалась в здание с криками "не дадим украсть выборы", "повесить Пенса", пытаясь добраться до зала заседаний. Охране удалось направить восставших по ложному пути, тем временем вывести депутатов коридорами в другие здания. Через три часа с помощью полиции Вашингтона здание Капитолия было освобождено от "повстанцев" и конгресс завершил работу, утвердив победу Д. Байдена. Во время штурма погибли четыре охранника и одна участница штурма.

В книге «Авторитарный кошмар: Трамп и его последователи" авторы показывают, что Трамп использовал авторитарные взгляды и настроения, которые давно существовали в американском обществе [Dean, Altemeyer, 2020].

Бытуют и более категоричные оценки распространения крайне правых взглядов среди населения страны. "Американская демократия продемонстрировала - с трудом, - что можно свергнуть фашистского лидера, - пишет обозреватель Р. Катнер,- - но труднее вытеснить фашистское население, когда фашизм живет в сердцах слишком многих людей. Трампизм, с Трампом лично, или без него, остается удручающе популярным. Неприкрытое насилие в Капитолии было лишь крайним примером неуклонного сползания к авторитаризму, который слишком охотно был принят большинством республиканских лидеров - и избирателей" ${ }^{1}$.

Основу изучения авторитарной личности заложил Теодор Адорно, выдающийся представитель Франкфуртской школы, одной из ведущих школ в философии, социологии прошлого века. Вместе с Адорно в Институте социальных исследований, созданным его коллегой Максом Хоркхаймером, изучением предрассудков, антисемитизма, авторитарного типа личности занимались также Герберт Маркузе, Эрих Фромм, Юрген Хабермас. Наряду с этими темами они рассматривали корни фашизма в массовом сознании. Они продолжили эту работу в эмиграции в США, в Принстоне и Беркли.

Здесь Адорно с коллегами разработали теоретическую базу изучения авторитаризма, показали, что антисемитизм является лишь одним из примеров авторитарного характера личности, который включает в себя конформизм, преклонение

\footnotetext{
1 Kuttner R. When Trump's Gone, Will Fascism Live On? //The American Prospect. 2021. January 8. URL: https://prospect. org/blogs/tap/when-trumps-gone-will-fascism-live-on/ (дата обращения: 22.04.2021).
} 
перед силой, властью, склонность к стереотипам, неприятие, подавление всего "чужого", нестандартного, выходящего за рамки принятых норм.

Важная социологическая задача, стоявшая перед исследователями, заключалась в разработке анкеты, вопросы которой смогут обнаружить черты авторитаризма, не обращаясь напрямую к темам антисемитизма или фашизма, выявляя скрытую предрасположенность к авторитарным идеям. Такая анкета была разработана и включала Шкалу-Ф (F-Scale), где "Ф» означало "фашизм", хотя анкета использовалась для определения авторитарных настроений в более широком смысле. Результаты социологических исследований, проведенных с помощью этой шкалы, легли в основу книги "Авторитарная личность", авторами которой были Т. Адорно, Э. Френкель-Брунсвик, Д. Левинсон и Р. Сэнфорд [Adorno et al., 1950]. В ней было сформулировано понятие “авторитарный синдром" и определены черты, характеризующие авторитарную личность: преклонение перед властью, слепая вера в авторитет лидера, иерархия социального и политического пространства и поиск внешнего врага, самоутверждение за счет унижения слабого, подчиненного, агрессивность и культ силы.

Специфика Шкалы-Ф заключалась в том, что вопросы формулировались попарно: "авторитарному" варианту соответствовал “антиавторитарный", анализ строился на латентных значениях ответов, каждый ответ шкалировался по силе утверждения - согласия и несогласия, им присваивался определенный балл, что позволяло оценивать респондентов как более или менее авторитарных.

Эти характеристики Шкалы-Ф, при всей критике ее деталей другими учеными, использовались в многочисленных сходных исследованиях черт личности, в частности склонности к авторитаризму.

Идеи и методы исследования Т. Адорно получили развитие в работах канадского социального психолога Роберта (Боба) Альтемейера [Altemeyer, 2007]. Он разработал шкалу "правого авторитаризма" - Right-wing authoritarianism (RWA). Под "правым" здесь имеются в виду не столько политэкономические категории, сколько морально-психологические - склонность к национализму, расизму, враждебности к иммигрантам. Соответственно, право-авторитарные личности могут иметь как правые, так и левые политические взгляды. Например, сталинский Советский Союз традиционно считается "левым" государством, но большинство сторонников Сталина были типичными правыми авторитаристами.

Анкета-шкала состоит из 22 суждений, половина которых авторитарные, а половина -антиавторитарные. При этом ключевые социальные установки авторитарной личности сводятся к трем чертам:

- авторитарное подчинение - готовность и желание подчиняться властям, которые считаются легитимными в данной социальной группе, лидеру, вождю носителю и символу этой власти;

- авторитарная агрессия - агрессивное поведение по отношению ко всем, кто не подчиняется этой власти, ко всем "чужим", инакомыслящим, аут-группам;

- конвенционализм, конформизм - приверженность ценностям и социальным нормам, разделяемым данной социальной группой и воспринимаемым как эталонные, «правильные» для всего общества. 
Свою концепцию развития авторитарной личности и результаты социологических исследований на ее основе Б. Алтемейер изложил в работах "Авторитарный спектр" (The Authoritarian Specter) и "Авторитаристы" (The Authoritarians). Его исследования распространенности авторитарных тенденций в США подтверждали оценки Адорно - наряду с давними традициями демократии, гуманизма, эгалитаризма в стране по-прежнему распространены расизм, "белый супрематизм", антисемитизм, неприятие иммиграции из ряда стран, в частности исламских, африканских, латиноамериканских, другие формы неприятия людей, придерживающихся иных, "чужих" взглядов и норм. Эти настроения, часто оформленные в движения, группы, секты, как-то контролируются, удерживаются в рамках законности государством, правоохранительными органами, но временами появляются политические лидеры, быстро набирающие авторитет, в том числе поддержку избирателей, использующие те или иные авторитарные, правые лозунги. Многие помнят консерватизм, авторитарные взгляды Барри Голдуотера или Рональда Рейгана, но в 2015 г. на политическом небосклоне появилась новая звезда авторитаризма - Дональд Трамп.

Еще до этого исследователи выясняли влияние авторитарных настроений на американскую политику. В книге «Авторитаризм и поляризация в американской политике» М. Хетерингтон и Дж. Вейлер [Hetherington, Weiler, 2009] пришли к выводу, что поляризация, разделяющая американское общество, в значительной степени объясняется не только социальным, экономическим или расовым расслоением, но и делением людей на придерживающихся авторитарных и неавторитарных взглядов. Это расслоение все больше возрастало в начале нового века с усилением иммиграционных потоков, увеличением доли небелого населения, экономических проблем белого рабочего класса, угрозы терроризма, изменениями морально-этических норм и ценностей (распространением культуры геев, однополых браков, разрешением продажи марихуаны и т. п.). Растущие страхи перед новыми вызовами привели к росту авторитарных потребностей и взглядов - стремлению к установлению “закона и порядка" и поиску сильного лидера, способного защитить от угроз и вернуть традиционный образ жизни.

Многие ученые выявляли эти тенденции роста авторитарных установок, используя варианты шкалы авторитаризма Б. Альтемейера. В то же время Стэнли Фельдман из Университета Stony Brook разработал тест из четырех вопросов, определяющих отношение к воспитанию детей, которые дают ключ к определению авторитарных склонностей человека: насколько респонденты ценят иерархию, порядок и конформизм [Feldman, Stenner, 1997]. Надо сказать, что сходные вопросы о воспитании детей были и в F-Scale T. Адорно.

Впервые этот блок вопросов был проверен в массовом опросе 1992 г.- регулярном исследовании американских избирателей National Election Study, в котором была возможность сравнить результаты с другими вопросами по социальнополитической тематике. Задавались следующие вопросы:

1. Скажите, пожалуйста, что, по вашему мнению, важнее для ребенка: независимость или уважение к старшим?

2. Скажите, пожалуйста, что, по вашему мнению, важнее для ребенка: послушание или уверенность в себе? 
3. Скажите, пожалуйста, что, по вашему мнению, важнее для ребенка: быть внимательным или хорошо себя вести?

4. Скажите, пожалуйста, что, по вашему мнению, важнее для ребенка: любопытство или хорошие манеры?

Эти вопросы затем часто используются в разных исследованиях для определения авторитарных склонностей респондентов. Затем они сравниваются с ответами на другие социально-политические вопросы для выявления корреляции.

С. Фельдман сопоставлял эти психологические замеры с реакцией на суждения, высказывания, распространенные в прессе, по поводу ряда острых проблем. В ходе опроса респондентов спрашивали, в какой степени они поддерживают, (сильно или частично) или решительно выступают против следующих пяти стратегий:

- использование военной силы вместо дипломатии против стран, угрожающих Соединенным Штатам;

- изменение Конституции, запрещающее давать гражданство детям нелегальных иммигрантов;

- дополнительные проверки в аэропорту пассажиров, которые, как представляется, имеют ближневосточное происхождение, чтобы обуздать терроризм;

- федеральная правительственная программа, в рамках которой все телефонные звонки сканируются, чтобы узнать, не поступают ли какие-либо звонки на телефонный номер, связанный с терроризмом;

- требование для всех граждан всегда иметь при себе национальное удостоверение личности, чтобы предъявить его в полицейское управление в целях борьбы с терроризмом.

Два шкальных вопроса предлагали оценить высказывания - является ли каждый из следующих показателей очень хорошим, хорошим, нейтральным, плохим или очень плохим для Америки:

- ограничения полномочий сотрудников полиции применять силу в ответ на недавние обвинения в жестокости полиции;

- американские мусульманские общины строят больше мечетей в американских городах.

Взятые вместе, эти семь вопросов в целом отражают готовность ограничить гражданские свободы американцев или членов групп меньшинств и выражают поддержку применения силы против тех, кто может угрожать стране, или потенциальных преступников [Feldman, 2020].

Результаты исследования автора показывают, что респонденты с высоким уровнем авторитарных настроений, выявленным на основе указанного психологического теста, в значительно большей степени поддерживают нетерпимость и репрессивные меры по отношению к группам, отличающимся от мейнстрима или несущим потенциальную угрозу. Так, они скорее готовы поддержать вооруженные действия, а не дипломатию в международных конфликтах, не давать гражданство детям незаконных иммигрантов, особо проверять людей в аэропортах, прибывающих с Ближнего Востока, организовать тотальное прослушивание телефонных переговоров при подозрении в связи с терроризмом, в этих же целях обязать всех всегда носить удостоверение личности для предъявления 
полиции. Также они не согласны с ограничениями полиции в применении силы из-за обвинений полиции в жестокости; они против строительства новых мечетей в стране.

Исследования С. Фельдмана во время республиканских первичных выборов в 2016 г. показали явную связь высокой степени авторитарных взглядов, нетерпимости и враждебности к представителям "иных" групп среди потенциальных сторонников Трампа, или, иначе, притяжение, "стекание" авторитаристов в лагерь избирателей Трампа.

С. Фельдман задается вопросом: если авторитарные настроения так распространены среди американского населения, может ли вообще либеральная демократия как-то их сдерживать, минимизировать, держать под контролем? В целом, считает автор, это удается сделать, особенно на уровне национальных выборов, поскольку политики, кандидаты стремятся привлечь голоса большинства электората, не пораженного авторитаризмом. Однако при определенных обстоятельствах может появиться политик, который постарается мобилизовать людей с авторитарными взглядами и ценностями - это ему удастся сделать с помощью вполне откровенных авторитарных лозунгов. Что и произошло в кампании 2016 г. и продолжалось до выборов 2020 г.

Трамп поддерживал многие традиционные концепции американских консерваторов, но наибольший политический успех среди избирателей ему принес "вульгарный популизм" (так его стиль и риторику часто описывала пресса), презрение и ненависть к политическим противникам, расизм и ксенофобия.

\section{Истоки трампизма}

Многие ярые сторонники Трампа, пишут Б. Альтемайер и Дж. Дин, «покорны, боязливы и жаждут могущественного лидера, который защитит их от жизненных угроз. Они делят мир на друзей и врагов, причем последние значительно превосходят числом первых" [Dean, Altemeyer, 2020: 6].

Личные авторитарные убеждения Трампа хорошо известны, и эксперты во многих академических областях предупреждают, что его нападки на основные демократические принципы представляют явную опасность для американской политической системы. Но его убеждения и действия бессильны без поддержки миллионов последователей.

Другие исследователи пришли к аналогичным выводам, применяя иные методы. Политолог Ларри Бартелс [Bartels, 2020], например, использовал данные опроса YouGov, чтобы обнаружить, что многие избиратели-республиканцы придерживаются сильных авторитарных и антидемократических убеждений, причем расизм выступает ключевым фактором этих взглядов. Исследователи также обнаружили, что отдельные показатели авторитарных убеждений, такие как отношение к воспитанию детей, являются надежными предикторами поддержки Трампа.

Эти исследования показали, что многие американцы выражают крайне авторитарные точки зрения. Примерно половина сторонников Трампа, например, согласились с утверждением: “Как только наши правительственные лидеры и власти осудят опасные элементы в нашем обществе, долгом каждого патриотичного гражданина будет помочь искоренить гниль, отравляющую нашу страну 
изнутри", что Альтемайер и Дин характеризуют как "практически нацистский призыв" ${ }^{2}$.

Современные исследователи американских массовых взглядов избирателей отмечают явления, похожие на те, что были в Германии после поражения в Первой мировой войне, а именно: утверждения политиков, что германская армия не проиграла войну, ее сдали левые, коммунисты и евреи в правительстве, которые капитулировали, предав нацию; эта теория заговора получила название "миф об ударе в спину" (Dolchstosslegende) ${ }^{3}$. В 2020 г. в США подобная тактика привела к позиции "остановите воровство выборов". Трамп начал готовиться к этой кампании еще за год до выборов: «Единственно, как мы можем проиграть, это если у нас украдут результаты выборов" ${ }^{4}$. Соответственно, проиграв выборы, Трамп всю послевыборную пропаганду строил на лозунге "у нас украли победу". С этим лозунгом его сторонники штурмовали Капитолий и с ним он собирается поднимать своих избирателей на следующие выборы.

Политолог Гарварда П. Норрис считает, что межнациональные исследования показывают, «насколько экстремистской стала Республиканская партия. С точки зрения своей позиции по отношению к принципам либеральной демократии она сейчас, по оценкам, ближе к авторитарным популистским партиям, таким как испанская Vox, нидерландская „Партия свободы“ и „Альтернатива для Германии“, чем к основным консервативным, христианско-демократическим и правоцентристским партиям" ${ }^{5}$.

«Большая часть сегодняшней Республиканской партии уже пронизана экстремизмом,- - пишет обозреватель Washington Post Ф. Закариа.-Согласно недавнему опросу Американского института предпринимательства, 56 \% республиканцев считают, что „традиционный американский образ жизни исчезает так быстро, что нам, возможно, придется применить силу, чтобы спасти его“. 39\% поддержали еще более сильное заявление: „Если избранные лидеры не будут защищать Америку, народ должен сделать это сам, даже если это потребует принятия насильственных мер“„6.

Хотя критика Трампа, его расистских высказываний, антидемократических действий, безрассудства и высокомерия достаточно широко распространена в обществе, в прессе, либеральных политических слоях и группах, опыт последних двух десятилетий и в частности двух избирательных кампаний показал, что правые, расистские, авторитарные взгляды и настроения в той или иной мере близки половине Америки.

\footnotetext{
2 Ingraham Ch. New Research Explores Authoritarian Mind-Set of Trump's Core Supporters //Washington Post. 2021. October 12. URL: https://www.washingtonpost.com/business/2020/10/12/trump-voter-authoritarian-research/ (дата обращения: 22.04.2021).

3 Bittner J. 1918 Germany Has a Warning for America //The New York Times. 2020. November 30. URL: https://www. nytimes.com/2020/11/30/opinion/trump-conspiracy-germany-1918.html (дата обращения: 22.04.2021).

4 Donald Trump 2020 RNC Speech Transcript August 24 //Rev. 2020. 24 August. URL: https://www.rev.com/blog/ transcripts/donald-trump-2020-rnc-speech-transcript-august-24 (дата обращения: 22.04.2021).

5 Norris P. It Happened in America. Democratic Backsliding Shouldn't Have Come as a Surprise //Foreign Affairs. 2021. January 7. URL: https://www.foreignaffairs.com/articles/united-states/2021-01-07/it-happened-america (дата обращения: 22.04.2021).

${ }^{6}$ Zakaria F. Mainstream Republicans Have Tolerated Extremism for Years. Can They Finally Control It? //The Washington Post. 2021. February 18. URL: https://www.washingtonpost.com/opinions/mainstream-republicans-have-toleratedextremism-for-years-can-they-finally-control-it/2021/02/18/f3c2cd72-722c-11eb-85fa-e0ccb3660358_story.html (дата обращения: 22.04.2021).
} 
Американская политическая система XIX и XX веков служила маяком, образцом для нарождающихся демократий во всем мире. Из всех аспектов демократии американская "свобода" служила притягательным символом для многих людей. После Второй мировой войны США внедрили с помощью сил оккупационной армии демократическую конституцию и политическое устройство в Германии и Японии. Да и остальные страны Европы, обладавшие своей богатой политической историей развития демократии, свободы печати, соревнования политических партий и выборов, многое в послевоенном устройстве перенимали из Америки.

При этом в Америке в это же самое время в полной мере существовала расовая сегрегация, законодательно ограничивавшая права чернокожего населения. Она была остановлена лишь в 1964 г. с принятием Билля о гражданских правах после десятилетий борьбы чернокожих и прогрессивной части белого общества. Трудно переоценить прогресс, который был достигнут в десегрегации с тех пор. Вероятно, главную роль в этом процессе сыграли армия, спорт и шоу-бизнес, целенаправленно и активно расширявшие равноправное участие чернокожих американцев в своей сфере деятельности. У жителей других стран, смотрящих американские кинофильмы или телепередачи, создавалось представление о радикальном прорыве в деле десегрегации в Америке, достижении реального расового равенства. Однако, несмотря на прогресс, реальное расовое и этническое равенство в Америке еще далеко от совершенства, что поддерживает особую сферу политической, предвыборной борьбы-борьбы расовых и национальных меньшинств за свои права.

Одновременно в Америке продолжают существовать на уровне массовых представлений расизм и шовинизм, прежде всего в виде идеи о «превосходстве белой расы». Эти авторитаристы в качестве аут-группы используют афроамериканцев как получающих, по их представлениям, несоразмерно высокую помощь от правительства по сравнению с белыми американцами, в частности неквалифицированными рабочими.

Другой источник пополнения рядов авторитаристов - религиозные фундаменталисты "евангелические христиане", которые в основном придерживаются консервативных позиций по социальным вопросам, в том числе в отношении смешанных браков, однополых браков, прав сексуальных меньшинств и т. п.

Важная часть идеологии авторитарных адептов - противодействие иммиграции. В стране иммигрантов это кажется странным и противоестественным. Но в то же время в американской истории было много периодов, когда новая волна иммигрантов, особенно с какой-либо новой этнической окраской, встречала активное неприятие “коренных американцев", иммигрировавших туда ранее.

\section{Раш Лимбо}

В плане создания авторитарного имиджа, стиля общения с массовой аудиторией, Д. Трамп много перенял у многолетнего популярного ведущего радиошоу крайне правой ориентации Раша Лимбо. Как пример его расовой паранойи приведем следующую цитату: «Это Америка Обамы, не так ли? Америка Обамы - белые дети, которых теперь избивают в школьных автобусах. Вы сажаете своих детей в школьный автобус, вы ожидаете безопасности, но в Америке Обамы белых детей теперь 
избивают, а черные дети кричат: „Ура, прямо сейчас, прямо сейчас“, и, конечно, все говорят - белый ребенок заслужил это, он родился расистом, он белый " ${ }^{7}$.

Характерна и такая мысль Р. Лимбо: дети иммигрантов из Центральной Америки распространяют болезни в Соединенных Штатах. Ее через несколько месяцев подхватил Трамп во время своего выдвижения: «Когда Мексика посылает своих людей, они не посылают своих лучших. Они не посылают вас. Они посылают людей, у которых много проблем, и они приносят эти проблемы с собой. Они везут наркотики. Они приносят преступления. Они насильники. Некоторые, я полагаю, хорошие люди» 8 .

Трамп и Лимбо нашли друг друга. Годы потребления консервативных СМИ, которые приняли вульгарный, презрительный, оскорбительный стиль Лимбо, отточили способность Трампа говорить на том же языке. Коллега Лимбо по радиошоу стал затем основателем медийной сети Fox News, в которой часто выступал Трамп. В благодарность за солидарность в финале своего президентского срока Трамп наградил Р. Лимбо президентской медалью Свободы.

Трамп симпатизировал, а часто открыто поддерживал организации крайне правого толка, такие как "Гордые мальчики" (Proud boys), "Хранители присяги" (Oath keepers), которые затем участвовали в штурме Капитолия. В одном из твитов он их настраивал: "Будьте наготове».

Одна из крайне правых групп "Ковбои за Трампа" вызывала особую его симпатию, он даже показывал на своем сайте их рекламный ролик с девизом "Хороший демократ - это мертвый демократ" ${ }^{9}$. Правда, позже запись была удалена с сайта.

Став мастером стиля агрессивных, крикливых представителей правых, расистских групп, оскорбляющих своих противников из либерально-демократического лагеря, движений расовых меньшинств, антифашистских групп, Трамп не жалел фантазии в придумывании оскорбительных кличек своим конкурентам из демократического лагеря. Если его грубость, вульгарные тирады во время выступлений в кампании 2016 г. дебатов кандидатов многие относили к издержкам американской политической культуры, часто сходной с эстрадным шоу или цирком, то за время его правления выяснилось, что это его собственный стиль, манера мышления и публичного общения. Оказалось, что расизм и антимусульманские выпады - это часть его идеологии, все аспекты авторитаризма являются частью его личности.

\section{Республиканцы - партия авторитаристов?}

Плацдармом авторитаризма стала Республиканская партия. Консервативные ценности и нормы американской политической культуры, такие как "малое» пра-

\footnotetext{
7 Friedersdorf C. Don't Read This If You Were a Rush Limbaugh Fan //The Atlantic. 2021. February 18. URL: https:// www.theatlantic.com/ideas/archive/2021/02/rush-limbaughs-rise-and-conservatisms-fall/618058/ (дата обращения: 22.04.2021).

8 Gabbatt A. Golden Escalator Ride: The Surreal Day Trump Kicked Off His Bid for President //The Guardian. 2019. June 14. URL: https://www.theguardian.com/us-news/2019/jun/13/donald-trump-presidential-campaign-speech-eyewitnessmemories/ (дата обращения: 22.04.2021).

9 Blake A. Trump Promoted N. M. Official's Comment That "the Only Good Democrat Is a Dead Democrat." Now the Man Is Arrested in the Capitol Riot//The Wasington Post. 2021. January 18. URL: https://www.washingtonpost.com/ politics/2021/01/18/trump-promoted-his-comment-that-only-good-democrat-is-dead-democrat-now-he-is-arrestedstorming-capitol/ (дата обращения: 22.04.2021).
} 
вительство, низкие налоги и, соответственно, ограниченное государственное регулирование, традиционно были ближе республиканцам. Однако реальные перемены в сторону авторитаризма начались в середине 1960-х годов, когда Республиканская партия стала превращаться в партию “закона и порядка" и "традиционных ценностей". В соответствии с так называемой южной стратегией партия выступала против гражданских прав, чтобы привлечь недовольных белых избирателей.

Начиная с 1970-х годов по большинству социальных проблем, по которым демократическая партия занимала либеральные позиции, привлекавшие избирателей - таким как расовые проблемы, национальная безопасность, преступность, гражданские права, однополые браки, терроризм, иммиграция,Республиканская партия все более представляла правые авторитарные позиции, чтобы привлечь избирателей, не согласных с либеральным подходом демократов.

В то же время все чаще партии и их лидеры отличались друг от друга не просто подходами к решению важных проблем, а взглядами на жизнь и управление страной. Некоторые республиканские лидеры нащупывали тягу избирателей к авторитаризму, другие - нет. Например, элита Республиканской партии уже три десятилетия стремится усилить свой электорат за счет растущего латиноамериканского населения, для чего они выступают за иммиграционную реформу, в то время как авторитаристы хотят более жесткой политики в отношении иммигрантов. Наиболее активных авторитаристов мало интересовало снижение налогов, которого упорно добивались республиканские политики.

Явным этот слой электората сделало рождение в 2009 г. “Движения чаепития» ${ }^{10}$, названного так по аналогии с “Бостонским чаепитием" во времена Американской революции. Тогда был протест против налогового давления на колонии британской метрополией, ныне это был протест против либерального государства, обирающего работающих тружеников и раздающего деньги "бездельникам" и "иждивенцам".

Эти настроения усилило выступление на конференции в Чикагской товарной бирже телеобозревателя Р. Сантелли о том, что программы Б. Обамы - это “субсидирование лузеров, вознаграждение не тех, кто носит воду, а тех, кто ее выпивает". "Сколько из нас хотят выплачивать ипотечные ссуды за наших соседей, у которых в доме есть второй туалет, но нет денег, чтобы платить по счетам» ${ }^{11}$. Сантелли предрек создание в Чикаго “Движения чаепития". Его призыв тут же подхватили правые медиаканалы, был создан специальный сайт, а вскоре - и тысячи региональных отделений.

Борьба против "субсидирования лузеров", "тех, кто выпивает воду, а не тех, кто ее носит", означала массовое неприятие самой концепции "социального государства", социальных реформ Ф. Рузвельта, либеральных программ "великого общества" и новых социальных программ Б. Обамы. Последний в этом ряду получил больше всего упреков: “Обама слишком благотворителен за счет других людей», $92 \%$ сторонников “Движения чаепития", по данным опроса «Нью-Йорк

\footnotetext{
${ }^{10}$ McGrath B. The Movement. The Rise of Tea Party Activism //The New Yorker. 2010. February 1. URL: https://www. newyorker.com/magazine/2010/02/01/the-movement (дата обращения: 22.04.2021).

${ }^{11}$ Ibidem.
} 
Таймс-Си-Би-Эс" ${ }^{12}$, считали, что "Обама ведет Америку к социализму". В целом его сторонники выступают против обеспечения государством общественного равенства и перераспределения благ сверху.

Американские правые и правые авторитаристы - всегда расисты. В США легко найти аут-группу, она всегда на виду - "черные». Но в "Движении чаепития" в изобилии представлены и другие расистские и националистические этнофобии - ненависть к азиатам, антисемитизм, исламофобия, неприятие иммигрантов вообще. Важным объектом нападок партии стал Б. Обама: мало того, что либерал, так еще и небелый. Неудивительно, что 95 \% сторонников “Движения чаепития" - белые.

"Движение чаепития" взбудоражило массовое недовольство властью, истеблишментом, в апреле 2009 г. на улицы вышли тысячные толпы. На промежуточных выборах 2010 г. 41 \% избирателей-республиканцев поддерживали "Движение чаепития", их голоса привели к потере демократами - сторонниками Обамы 63 мест в Палате представителей, 6 постов губернаторов - и это после победы Обамы на президентских выборах за два года до этого.

В соответствии с американским избирательным законодательством, "Движение чаепития" не было партией. Тем не менее оно стало мощным популистским течением, в тот момент питавшим поддержкой наиболее право-консервативных лидеров Республиканской партии. Им не хватало яркого авторитарного лидера - через несколько лет он появился.

Дональд Трамп понял и использовал все сантименты и лозунги сторонников "Движения чаепития", так же как и других право-радикальных групп и течений. Социологические исследования показали, что сторонников таких движений миллионы, по результатам последних выборов, избирателей Трампа - 75 млн.

\section{Накануне выборов 2020 г.}

В исследовании авторитаризма 2019 г., указанном выше, Дж. Дин и Б. Альтемайер [Dean, Altemeyer, 2020] опирались в основном на шкалу «правого авторитаризма" (RWA) Альтемейера. Она измеряет согласие или несогласие респондентов c 20 утверждениями, такими как:

- "Наша страна отчаянно нуждается в могущественном лидере, который сделает то, что должно быть сделано, чтобы уничтожить радикально новые пути и греховность, которые губят нас";

- «Всегда лучше доверять суждению соответствующих властей в правительстве и религии, чем слушать шумных подстрекателей в нашем обществе, которые пытаются посеять сомнения в умах людей".

Для каждого утверждения респондент мог выбрать ответ по шкале от 1 (полное несогласие) до 9 (полное согласие). Итоговый балл по опросу из 20 вопросов колеблется от 20 (общая оппозиция авторитаризму) до 180 (общая поддержка).

Авторы заручились помощью Института опросов Монмутского университета, чтобы задать эти вопросы 990 американским избирателям осенью 2019 г. Они предложили участникам ответить на вопросы по шкале RWA, а также на некоторые

\footnotetext{
12 The New York Times-CBS News Poll. National Survey of Tea Party Supporters. April 5-12, 2010. URL: https://www. nytimes.com/interactive/projects/documents/new-york-timescbs-news-poll-national-survey-of-tea-party-supporters (дата обращения: 22.04.2021).
} 
показатели авторитарных убеждений и предубеждений по отношению к группам меньшинств.

При организации этого исследования директор Института опросов Монмутского университета Патрик Меррей [Murray, 2020a] исходил из представлений Альтемейера, что традиционные религиозные ценности в большой мере пронизаны авторитаризмом, преклонением перед сакральным авторитетом и связаны со светскими авторитарными оценками. Тем не менее он решил проверить эту близость, выделив религиозные ценности в отдельную анкету, и затем сравнить полученные ответы. Вопросы о сексуальной морали были выделены в отдельную анкету.

Таким образом получилась анкета, в которую были добавлены два вопроса о приверженности к сильному лидеру:

1. Наша страна отчаянно нуждается в могущественном лидере, который сделает то, что должно быть сделано, чтобы уничтожить радикальные новые пути и греховность, которые губят нас.

2. Всегда лучше доверять суждениям соответствующих авторитетов в правительстве и религии, чем слушать шумных подстрекателей толпы в нашем обществе, которые пытаются посеять сомнения в умах людей.

3. Единственный способ, которым наша страна может преодолеть грядущий кризис, - это вернуться к традиционным ценностям, поставить у власти некоторых жестких лидеров и заставить замолчать смутьянов.

4. Наша страна нуждается в свободомыслящих людях, которые имеют мужество бросить вызов традиционным путям, даже если это расстраивает многих людей.

5. "Старомодный образ жизни" и "старомодные ценности" все еще показывают лучший способ жить.

6. Что действительно нужно нашей стране, так это сильный, решительный лидер, который сокрушит зло и вернет нас на наш истинный путь.

7. Наша страна будет великой, если мы будем чтить пути наших предков, делать то, что нам говорят власти, и избавимся от "гнилых яблок", которые все разрушают.

8. Нет «единственного правильного пути», как прожить жизнь; каждый должен создать свой собственный путь.

9. Эта страна работала бы намного лучше, если бы определенные группы нарушителей порядка просто заткнулись и заняли традиционное место своей группы в обществе.

10. Как только лидеры нашего правительства и власти осудят опасные элементы в нашем обществе, долг каждого патриотически настроенного гражданина будет заключаться в том, чтобы помочь искоренить гниль, отравляющую нашу страну изнутри.

11. Для лидера важнее уметь пробуждать глубинные чувства простого человека, чем предлагать хорошо аргументированные положения.

В исследование также была включена шкала ориентации на социальное доминирование - Social Dominance Orientation (SDO), которая выявляет предпочтения поддерживания иерархии в обществе: 
1. Некоторые группы людей должны оставаться на своих местах в обществе.

2. Вероятно, хорошо, что некоторые группы находятся наверху, а другие - внизу.

3. Идеальное общество требует, чтобы некоторые группы были на вершине общества, а другие - на дне.

4. Некоторые группы людей просто уступают другим группам.

5. Группы, находящиеся внизу, заслуживают всего того же, что и группы наверху.

6. Ни одна группа не должна доминировать в обществе.

7. руппы внизу не должны всегда оставаться внизу.

8. Групповое доминирование - плохой принцип.

9. Не следует стремиться к равенству групп.

10. Мы не должны стремиться гарантировать, что каждая группа будет иметь одинаковое качество жизни.

11. Несправедливо делать группы равными.

12. Равенство групп не должно быть нашей главной целью.

13. Мы должны работать, чтобы дать всем группам равные шансы на успех.

14. Надо сделать все возможное, чтобы уравнять условия для разных групп.

15. Независимо от того, сколько усилий это потребует, мы должны стремиться к тому, чтобы все группы имели равные шансы в жизни.

16. Равенство групп должно быть нашим идеалом.

Исследование выявило отчетливую линейную связь между поддержкой Д. Трампа и авторитарным мышлением: чем больше люди набирали баллов по шкале RWA, тем сильнее они поддерживали Трампа. Люди, заявляющие, что они сильно не одобряют деятельность Трампа, имели средний балл RWA 54. Те, кто указывал на полную поддержку президента, имели средний балл 119.

В таблице 1 показана корреляция поддержки, одобрения Трампа и степень авторитарности избирателей. Как отмечалось выше, по указанным шкалам степень согласия с оценками варьируется от 1 до 9 баллов, соответственно, самый низкий уровень авторитаризма может составить 20 баллов, а самый высокий - 180 .

Таблица 1. Степень одобрения деятельности Tрампа и баллы по шкале RWA.

\begin{tabular}{|c|c|c|c|c|}
\hline & $\begin{array}{c}\text { Полностью } \\
\text { одобряю }\end{array}$ & $\begin{array}{c}\text { Частично } \\
\text { одобряю }\end{array}$ & $\begin{array}{c}\text { Частично } \\
\text { не одобряю }\end{array}$ & $\begin{array}{c}\text { Совсем } \\
\text { не одобряю }\end{array}$ \\
\hline $\begin{array}{c}\text { Шкала RWA - } \\
20 \text { пунктов }\end{array}$ & 54 & 82 & 101 & 119 \\
\hline $\begin{array}{c}\text { Шкала RWA - } \\
11 \text { пунктов }\end{array}$ & 56 & 79 & 96 & 90 \\
\hline $\begin{array}{c}\text { Шкала SDO } \\
\text { (подсчитана по баллам RWA) }\end{array}$ & 45 & 70 & 81 \\
\hline
\end{tabular}

Источник: [Murray, 2020a].

В исследовании отмечается, что не все сторонники Трампа отличаются максимальным авторитаризмом взглядов, некоторые поддерживают его позиции по отдельным важным проблемам (например, иммиграция, расизм, владение 
оружием и т. п.) или исходят из образования, возраста и др. Тем не менее вот как различается степень авторитарности среди различных групп республиканцев (см. табл. 2).

Таблица 2. Оценки по шкалам RWA и SDO среди избирателей-республиканцев (в баллах
\begin{tabular}{|l|c|c|}
\hline & Баллы по шкале RWA & Баллы по шкале SDO \\
\hline $\begin{array}{l}\text { Все республиканцы } \\
\text { и близкие к республиканцам }\end{array}$ & 112 & 86 \\
\hline Мужчины & 113 & 88 \\
\hline Женщины & 111 & 83 \\
\hline Возраст 18-44 & 95 & 82 \\
\hline Возраст 45-64 & 110 & 90 \\
\hline Возраст 65+ & 118 & 89 \\
\hline Средняя школа или меньше & 120 & 86 \\
\hline Несколько лет колледжа & 120 & 86 \\
\hline 4-летний коллдж & 108 & 84 \\
\hline Выше колледжа & 102 & 87 \\
\hline Белые & 112 & 83 \\
\hline Небелые & 109 & 84 \\
\hline
\end{tabular}

Источник: [Murray, 2020b].

Максимальная поддержка у Трампа была в группе людей, у которых высокие баллы и по шкале авторитаризма правого крыла, и по шкале социального доминирования. Среди тех, кто полностью одобрял деятельность Трампа, таких было 32 \%.

Один вопрос в исследовании, которое проводилось в октябре 2019 г., не только дал пищу для научного анализа, но и оказался прогностическим. Комментируя его результаты в августе 2020 г., задолго до вашингтонских событий января 2021 г. - штурма Капитолия сторонниками Трампа, П. Мерей пишет: «Я не большой поклонник гипотетических вопросов. Есть слишком много случаев, когда то, что люди думали, что они будут делать в данной ситуации, не совпадает с их действиями, когда они оказываются в реальной ситуации. Но эти результаты действительно показывают, что у Трампа есть реальная база избирателей с высоким уровнем RWA/SDO, которые могут выйти на бастионы за него, и другая группа избирателей с высоким уровнем RWA, которые молчаливо предложат свою поддержку. Вопрос в том, образуют ли эти две группы критическую массу в американской политике" [Murray, 2020a: 4]. Описанные выше события в Капитолии показывают, что "критическая масса" образовалась. Вот как был сформулирован этот вопрос (см. табл. 3). 
Таблица З. Согласие/несогласие с утверждением “Трамп должен продолжать оставаться на своем посту, несмотря на проигрыш, если он объявит, что выборы были фиксированными и результат поддельный"

\begin{tabular}{|l|c|c|c|c|c|}
\hline $\begin{array}{c}\text { Все } \\
\text { избиратели }\end{array}$ & $\begin{array}{c}\text { Высокие } \\
\text { балы } \\
\text { по RWA\&SDO }\end{array}$ & $\begin{array}{c}\text { Высокие } \\
\text { баллы } \\
\text { только по RWA }\end{array}$ & $\begin{array}{c}\text { Высокие } \\
\text { баллы } \\
\text { только по SDO }\end{array}$ & $\begin{array}{c}\text { Средние } \\
\text { баллы } \\
\text { nо RWA\&SDO }\end{array}$ & $\begin{array}{c}\text { Низкие } \\
\text { баллы } \\
\text { по RWA\&SDO }\end{array}$ \\
\hline Согласен & $23 \%$ & $19 \%$ & $5 \%$ & $5 \%$ & $1 \%$ \\
\hline $\begin{array}{l}\text { Нейтральное } \\
\text { отношение }\end{array}$ & 24 & $15 \%$ & $16 \%$ & $10 \%$ & $1 \%$ \\
\hline Не согласен & $53 \%$ & $66 \%$ & $79 \%$ & $85 \%$ & $98 \%$ \\
\hline
\end{tabular}

Источник: [Murray, 2020a].

Почти четверть участников опроса с "двойной" авторитарной ориентациейпо двум шкалам RWA и SDO - требовали, чтобы Трамп остался в Белом доме, несмотря на проигрыш, поскольку он заявил «не дадим украсть наши выборы». И эти люди были готовы применить силу в защиту “своего" президента, что показал штурм Капитолия 6 января 2021 г. Если бы руководители охраны Капитолия читали научные журналы, они бы поняли, что разговоры о растущем авторитаризме среди американского населения вполне могут вылиться в "народное восстание", если к этому призывает авторитарный президент, и подтянули бы к себе в помощь войска.

Опрос университета Куиннипиак (Quinnipiac University National Poll, 2021) после судебного процесса над Трампом в сенате показал, что республиканцы по-прежнему стоят стеной за своего поверженного лидера, неважно, что считает остальная Америка (таблицы 4, 5).

Таблица 4. Считаете ли Вы, что президент Трамп ответственен за побуждение к насильственным действиям по отношению к органам власти? (в \%)

\begin{tabular}{|c|c|c|c|c|c|c|c|c|c|c|}
\hline & Всего & Респ. & Дем. & Нез. & Муж. & Жен. & $\begin{array}{c}\text { Кол. } \\
\text { обр. }\end{array}$ & $\begin{array}{c}\text { Без } \\
\text { кол. }\end{array}$ & $\begin{array}{c}\text { Бе- } \\
\text { лые. }\end{array}$ & $\begin{array}{c}\text { Не- } \\
\text { бел. }\end{array}$ \\
\hline Да & 54 & 11 & 96 & 52 & 45 & 62 & 66 & 36 & 47 & 68 \\
\hline Нет & 43 & 89 & 4 & 41 & 52 & 34 & 33 & 61 & 51 & 27 \\
\hline $\begin{array}{c}\text { Затр. } \\
\text { ответить }\end{array}$ & 4 & - & - & 6 & 3 & 4 & 1 & 3 & 2 & 5 \\
\hline
\end{tabular}

Источник: Quinnipiac University National Poll. 2021. February 15. URL: https://poll.qu.edu/national/release-detail? ReleaselD=3691 (дата обращения: 21.04.2021).

Таблица 5. (Если ответ "да" на предыдущий вопрос). Считаете ли Вы, что он должен быть привлечен к уголовной ответственности за побуждение к насильственным действиям по отношению к органам государственной власти? (в \%)

\begin{tabular}{|c|c|c|c|c|c|c|c|c|c|c|}
\hline & Всего & Респ. & Дем. & $\begin{array}{c}\text { Не- } \\
\text { завис. }\end{array}$ & Муж. & Жен. & $\begin{array}{c}\text { Кол. } \\
\text { обр. }\end{array}$ & $\begin{array}{c}\text { Без } \\
\text { кол. }\end{array}$ & $\begin{array}{c}\text { Бе- } \\
\text { лые. }\end{array}$ & $\begin{array}{c}\text { Не- } \\
\text { бел. }\end{array}$ \\
\hline Да & 45 & 6 & 85 & 42 & 35 & 54 & 56 & 30 & 39 & 57 \\
\hline Нет & 6 & 3 & 7 & 7 & 7 & 4 & 6 & 3 & 4 & 8 \\
\hline $\begin{array}{c}\text { Не ответ- } \\
\text { ственен }\end{array}$ & 43 & 89 & 4 & 41 & 52 & 34 & 33 & 61 & 51 & 27 \\
\hline $\begin{array}{c}\text { Затр. } \\
\text { ответить }\end{array}$ & 7 & 2 & 4 & 9 & 6 & 7 & 5 & 5 & 5 & 8 \\
\hline
\end{tabular}


Даже на мягкую форму критики Трампа за его действия после выборов - «формальное осуждение действий президента сенатом" - согласились 44\% всего населения и лишь $16 \%$ республиканцев при $75 \%$ демократов, поддержавших такое осуждение. По логике республиканцев, гнев Дональда Трампа был оправдан - даже если он призывал своих сторонников к насильственным действиям,- - поскольку "он искренне полагал, что результаты выборов были сфальсифицированы". Так считают $84 \%$ республиканцев при $8 \%$ демократов и 42\% всего населения в целом по стране.

Вся Америка и многие люди за границей следили за драматичным судом в сенате, который должен был выяснить голосованием, готов ли сенат вынести импичмент бывшему президенту Трампу; незадолго до этого Палата представителей, где большинство членов демократы, импичмент вынесла. Половина сената (50 человек) - республиканцы, из них для вынесения импичмента должны были проголосовать "за" 27 сенаторов. За импичмент выступили только семь республиканских сенаторов. Похожую картину показал и массовый опрос (см. табл. 6).

Таблица 6. Вы поддерживаете или не поддерживаете осуждение бывшего президента Трампа в сенате? (в \%)

\begin{tabular}{|c|c|c|c|c|c|c|c|c|c|c|}
\hline & Всего & Респ. & Дем. & Нез. & Муж. & Жен. & $\begin{array}{c}\text { Кол. } \\
\text { обр. }\end{array}$ & $\begin{array}{c}\text { Без } \\
\text { кол. }\end{array}$ & $\begin{array}{c}\text { Бе- } \\
\text { лые. }\end{array}$ & $\begin{array}{c}\text { Не- } \\
\text { бел. }\end{array}$ \\
\hline Да & 51 & 9 & 92 & 50 & 42 & 59 & 63 & 35 & 45 & 63 \\
\hline Нет & 44 & 89 & 6 & 44 & 53 & 37 & 34 & 62 & 52 & 30 \\
\hline $\begin{array}{c}\text { Затр. } \\
\text { ответить }\end{array}$ & 5 & 1 & 3 & 6 & 5 & 5 & 3 & 3 & 3 & 7 \\
\hline
\end{tabular}

Источник: Quinnipiac University National Poll. 2021. February 15. URL: https://poll.qu.edu/national/release-detail? ReleaselD=3691 (дата обращения: 21.04.2021).

Если сенат не осудил Трампа, то республиканцы не видят, почему он не может продолжать играть важную роль в Республиканской партии: $75 \%$ хотели бы, чтобы он играл важную роль, лишь $21 \%$ не хотели бы этого. Среди демократов соотношение $3 \%$ : $96 \%$, среди населения в целом - 34\%: $60 \%$. Еще больше республиканцев выступают за то, чтобы Трамп в будущем мог избираться на выборную должность - 87\%: 11\%, категорически против демократы -6\%: 93\%, хотя среди всего населения почти половина (43\%: $55 \%$ ) готова увидеть Трампа в списках кандидатов на выборах ${ }^{13}$.

\section{трампизм остается}

С уходом Трампа из Белого дома не ушли из политики многие его сторонники. Более того, штурм Капитолия сторонниками Трампа и процесс над ним с попытками импичмента показали, что большинство членов Республиканской партии по-прежнему поддерживают его и его сторонников - правых экстремистов и готовы снова видеть его на высоких государственных постах. Помимо этого, авторитарные настроения по-прежнему широко распространены в американском массовом сознании.

\footnotetext{
${ }^{13}$ Quinnipiac University National Poll. 2021. February 15. URL: https://poll.qu.edu/national/release-detail? ReleaselD= 3691 (дата обращения: 21.04.2021).
} 
П. Норрис подчеркивает, что проблема заключается в самой электоральной базе Республиканской партии: за последние десятилетия заметно ослабли основы американской гражданской культуры - доверие к правительству, доверие к политической системе и поддержка демократии. В 1995 г. 25 \% американцев в опросе ответили, что "хорошая идея - иметь сильного лидера, которому не нужно беспокоиться о парламенте и выборах". К 2017 г. таких стало 38\%. "Таким образом, Трамп бросил зажженную спичку в лужу бензина, когда заявил, что Байден украл выборы»14.

Как отмечено выше, распространены и более категоричные оценки расцвета крайне правых взглядов среди населения страны. "Американская демократия продемонстрировала - с трудом, - что можно свергнуть фашистского лидера,пишет обозреватель Р. Катнер, - но труднее вытеснить фашистское население, когда фашизм живет в сердцах слишком многих людей ${ }^{15}$.

Все больше данных о том, что в обществе растут социальные противоречия между разными "американцами", - по принципу расы, этничности, социального положения, дохода, образования, возраста, географии проживания. Многие аналитики в прессе считают, что различия между частями, слоями общества столь велики, что спасти страну от гражданской войны может только разделение на два государства, как в XIX веке, на "Север" и "Юг", или "Конфедеративные штаты" и “Соединенные штаты". Сейчас речь идет о штатах, в основном поддержавших Трампа, и тех, которые в основном выступают за Байдена, то есть "республиканские" штаты против "демократических", "красные" против "синих".

\section{Заключение}

Исследования авторитаризма в США показывают, что авторитарные тенденции в массовых настроениях, и ценностях и взглядах американцев, стиле управления и характере американских политиков существовали всегда. Сама история американской нации заложила предпосылки к этому. Красивая идея "плавильного котла", сплавляющего в единую нацию иммигрантов, отверженных из разных стран, разных рас и национальностей, безусловно, привлекала и привлекает людей всего мира. Но в ней с самого начала был заложен подрывной заряд - рабство и расизм. "Плавильный котел" успешно сплавлял ирландцев, сицилийских итальянцев, российских евреев, китайцев, малайцев, молокан и меннонитов, но он не смог "растворить" в единой американской нации африканскую кровь. Расизм, или иначе, "белый супрематизм", продолжает существовать и служит питательной почвой авторитаризма. Как было показано выше, авторитаризму нужен "образ врага", чтобы объяснить проблемы и угрозы в жизни, нужны «черные», “желтые», евреи, “пришельцы". Если в России евреи периодически назначались аут-группой, виновниками всех бед, а временами антисемитизм становился малозаметным, почти отсутствовал, то в США «белый супрематизм» был постоянной питающей средой авторитаристски настроенных групп.

\footnotetext{
$\overline{14}$ Norris P. It Happened in America. Democratic Backsliding Shouldn't Have Come as a Surprise //Foreign Affairs. 2021. January 7. URL: https://www.foreignaffairs.com/articles/united-states/2021-01-07/it-happened-america (дата обращения: 22.04.2021).

${ }^{15}$ Kuttner R. When Trump's Gone, Will Fascism Live On? //The American Prospect. 2021. January 8. URL: https://prospect. org/blogs/tap/when-trumps-gone-will-fascism-live-on/ (дата обращения: 22.04.2021).
} 
В последние два десятилетия к этому "классическому" расизму прибавилась ксенофобия. В Америке всегда была тенденция рассматривать каждую новую волну иммигрантов как людей "второго сорта" - "мы коренные жители, а они приезжие". Через это прошли все этнические волны - ирландцы, шведы, немцы, поляки, русские евреи. Потом эти "новички" становились "старожилами" и относились к вновь прибывающим с тем же высокомерием или отторжением.

Первые два века американской республики "плавильный котел", состоял в своем большинстве из многих этнических групп, указанных выше, но основную "сплавляющую" роль, или "ядро конденсации", играли белые англо-саксонские протестанты, которые в послевоенное время стали называться WASP. Эта культура Америки переплавляла все прибывавшие этнические, религиозные, культурные группы и их отличия. С недавнего времени ситуация шаг за шагом меняется. Через десять-пятнадцать лет американский «плавильный котел» будет уже в своей массе не белым, не англо-саксонским и не протестантским. Это демографическая статистика, но ее чувствует большинство американцев, особенно правых взглядов.

Изменения будут действительно радикальными: если в прошлом веке типичный "американец" во всем мире представлялся как англоговорящий с американским акцентом, белый массивного телосложения, то скоро этот образ кардинально изменится. По крайней мере, в Европе типичный американец скоро будет похож на "типичного бразильца", по крайней мере, по смуглости кожи.

В целом аргументы о растущей поляризации политических сил и движений, разделении социальных слоев и групп и факторах, питающих эту поляризацию, вполне обоснованны. Однако в них имеется существенный дисбаланс. Социалистические идеи в Америке имеют тенденцию к росту, во всяком случае, в массовом сознании и белых, и черных растет чувство несправедливости социального устройства страны, несправедливого распределения национального богатства, доходов между гражданами.

В то же время за последние годы резко выросло движение небелого населения за свои права. Это совпало во времени с политическими дискуссиями последней избирательной кампании.

Третья главная проблема, разделяющая страты американского общества, это проблема иммигрантов. Численность приезжих скоро превысит количество "коренных" жителей (насколько условным это понятие ни было бы для иммигрантской страны), и это неизбежно питает авторитарные тенденции.

Как показали социологические исследования последних лет, начиная с выборов 2016 г. у Трампа сформировалась обширная база, в основном среди представителей Республиканской партии, готовая во всем поддерживать его, разделяющая его авторитарные взгляды. Многие считают, что это уже не республиканцы, это третья партия - "авторитаристы Трампа", и с ними в том или ином электоральном качестве придется иметь дело демократам Дж. Байдена следующие четыре года.

\section{Список литературы (References)}

Adorno T. W., Frenkel-Brunswik E., Levinson D. J., Sanford R. N. (1950) The Authoritarian Personality. New York; London: Harper \& Row. 
Altemeyer R. (2007) The Authoritarians. Manitoba: University of Manitoba.

Bartels L. M. (2020) Ethnic Antagonism Erodes Republicans' Commitment to Democracy. PNAS. Vol. 117. No. 37. P. 22752-22759. https://doi.org/10.1073/pnas. 2007747117.

Dean J.W., Altemeyer B. (2020) Authoritarian Nightmare: Trump and His Followers. N.Y.: Melville House.

Feldman S., Stenner K. (1997) Perceived Threat and Authoritarianism. Political Psychology. Vol. 18. No. 4. P. 741-770.

Feldman S. (2020) Authoritarianism, Threat, and Intolerance. In: Borgida E., Federico Ch.M., Miller J. M. (eds.) At the Forefront of Political Psychology. New York: Routledge. DOI: https://www.doi.org/10.4324/9780429351549-4.

Hetherington M. J., Weiler J.D. (2009) Authoritarianism and Polarization in American Politics. Cambridge: Cambridge University Press.

Murray P. (2020a) Authoritarian Tendencies in the American Electorate (Part 1). URL: https://www.monmouth.edu/polling-institute/2020/08/25/authoritariantendencies-in-the-american-electorate-part-1/ (дата обращения: 21.04.2021).

Murray P. (2020b) Authoritarian Tendencies in the American Electorate (Part 2). URL: https://www.monmouth.edu/polling-institute/2020/08/25/authoritarianismamong-pro-and-anti-trump-voters-part-2/ (дата обращения: 21.04.2021). 